\title{
Studi Pengaruh Penggunaan Asam Laktat dari Sauerkraut sebagai Bahan Pengawet terhadap Kandungan Protein dan Lemak Total Udang Werus (Metapenaeus monoceros) selama Penyimpanan *)
}

\author{
Bonaventura Pura T. dan Nurul Lailana S.S \\ Jurusan Kimia ITS,Kampus ITS,Sukolilo Surabaya 60000
}

\begin{abstract}
Abstrak
Asam laktat yang terkandung dalam sauerkraut telah diujikan pada udang werus (Metapenaeus monoceros) sebagai bahan pengawet dengan konsentrasi $0,02 \mathrm{M}$ dan masa penyimpanan 0-8 jam. Selanjutnya dilakukan pengamatan terhadap kandungan protein dan lemak total udang werus. Metode yang digunakan adalah kjeldahl untuk analisa protein dan ekstraksi padat cair (ekstraksi soklet) untuk analisa lemak total. Hasil analisa pada 8 jam penyimpanan menunjukkan bahwa dengan penambahan asam laktat kandungan protein mengalami penurunan sebesar $45,46 \%$ sedangkan tanpa penambahan asam laktat mengalami penurunan sebesar $59,23 \%$. Kandungan lemak total dengan penambahan asam laktat turun sebesar $84,03 \%$ sedangkan tanpa penambahan asam laktat turun sebesar $84,15 \%$. Dari hasil tersebut di atas tampak bahwa asam laktat sebagai bahan pengawet berpengaruh terhadap kandungan protein dan lemak total udang werus. Asam laktat bersifat antimikroba terhadap bakteri-bakteri pembusuk pada udang werus sehingga protein dan lemak total yang terurai/terhidrolisis lebih kecil dibandingkan apabila tanpa ditambahkan asam laktat.
\end{abstract}

Kata kunci : asam laktat, sauerkraut, Metapenaeus monoceros, antimikroba.

\section{Effect of Lactic Acid from Sauerkraut as Preservative to Protein and Total Fat Content in Werus Shrimp (Metapenaeus monoceros) during storage}

\begin{abstract}
Lactic acid in sauerkraut has been tested as a preservative in Werus Shrimp (Metapenaeus monoceros) with concentration $0.02 \mathrm{M}$ and time preservation $0-8$ hours. After preservation, protein and total fat in shrimp was observed. The content of protein was analized using kjeldahl methode and the content of total fat was analized using soxlet extraction. After 8 hours preservation, the result showed that with adding lactic acid, the content of protein decreased $45.46 \%$ an without adding lactic acid decreased $59.23 \%$ whereas the content of total fat with adding lactic acid decreased $84.03 \%$ and without ading lactic acid decreased $84.15 \%$. According to these result, lactic acid as a preservative influence the content of protein an total fat in Werus shrimp. Lactic acid as a antimicrobial has ability againts bacteria which can hidrolize protein and fat so with adding lactic acid, the content of protein and total fat larger than without adding lactic acid.
\end{abstract}

Key word : lactic acid, sauerkraut, Metapenaueus monoceros, antimicrobial

*) Telah diseminarkan pada hari Kamis 27 April 2000 dalam Seminar Nasional
Perkembangan Peneliti Wanita, di Jurusan Kimia FMIPA Undip

No. artikel : $66 / 2000$ 


\section{PENDAHULUAN}

Ikan merupakan bahan pangan yang kaya protein tetapi bila . dibandingkan dengan bahan pangan lainnya, ikan merupakan bahan pangan yang sangat mudah mengalami pembusukan. Hal ini disebabkan oleh kandungan air yang cukup tinggi (70$80 \%$ dari berat daging) yang menyebabkan mikroorganisme mudah untuk tumbuh dan berkembang biak, adanya enzim yang dapat menguraikan protein menjadi putresin, isobutilamin, kadaverin, dan lain-lain yang menyebabkan bau tidak sedap, adanya asam lemak tak jenuh ganda berantai panjang yang sangat mudah mengalami proses oksidasi/hidrolisis menghasilkan bau tengik dan jaringan sel pada ikan yang lebih longgar menyebabkan mikroba dapat dengan mudah menggunakannya sebagai media pertumbuhan [1]. Keadaan ini sangat merugikan karena banyak ikan tidak dapat dimanfaatkan dan terpaksa harus dibuang, terutama pada saat melimpah. Oleh karena itu, untuk mencegah proses pembusukan perlu dikembangkan berbagai cara pengawetan yang cepat agar ikan dapat dimanfaatkan [2].

Menurut Lindgren dan Dobrogosz (1990) penambahan BAL dapat memperpanjang masa simpan dan menghambat pertumbuhan bakteri patogen pada berbagai jenis produk daging [3].

Pada tahun 1997, Srikandi Fardiaz dan kawan-kawan telah melakukan isolasi dan seleksi BAL yang berhasil diisolasi dari produk fermentasi kubis (sauerkraut) yaitu Lactobacillus plantarum dan $\mathrm{L}$. brevis. Isolat BAL tersebut cukup memberikan penghambatan terhadap pertumbuhan bakteri patogen dan perusak yang sering terdapat pada ikan segar dikarenakan sifat antimikrobanya [4].

Dan pada tahun yang sama, B. Sri Laksmi Jenie dan kawan-kawan telah melakukan pengawetan ikan lemuru dalam bentuk segar dengan menggunakan kultur starter campuran BAL terseleksi yang dikombinasikan dengan garam $\mathrm{NaCl}$ dan Na-asetat. Pada penyimpanan suhu kamar kesegaran ikan lemuru dapat dipertahankan sampai 36 jam sedangkan ikan lemuru kontrol kurang dari 12 jam dan pada suhu dingin (3$\left.7^{\circ} \mathrm{C}\right)$ kesegaran ikan lemuru dapat bertahan 15 hari sedangkan kontrol hanya 6 hari [5].

Udang merupakan salah satu hasil perikanan, termasuk ke dalam kelompok krustasea yaitu jenis ikan berlemak medium. Udang diklasifikasikan menjadi dua yaitu udang laut antara lain Penaeus monodon (udang windu), Penaeus merguiensis (udang putih) dan Metapenaeus monoceros (udang werus/udang dogol/udang laki) selain itu juga terdapat udang air tawar antara lain Macrobrachium rosenbergii (udang galah), Panalirus spp (udang kipas) dan lobster (udang karang). Contoh-contoh di atas termasuk udang yang memiliki nilai ekonomi yang penting.

Udang memerlukan penanganan yang lebih intensif dalam pemasarannya sebab udang cepat sekali mengalami pembusukan dibanding dengan hasil perikanan lainnya dimana protein yang ada akan terurai dan lemak yang terkandung di dalam daging udang werus akan mudah teroksidasi/terhidrolisis sehingga dapat menurunkan mutu dan nilai gizinya.

Permasalahan yang ada apakah asam laktat yang terkandung di dalam 
sauerkraut berpengaruh terhadap kandungan protein dan lemak total ikan dalam hal ini udang werus. Sedangkan peneliti yang terdahulu tidak menguji pengaruh asam laktat dengan kandungan protein dan lemak total pada daging ikan. Maka berdasarkan latar belakang yang ada perlu dilakukan penelitian seberapa jauh asam laktat berpengaruh sehingga dapat digunakan sebagai bahan pengawet pada udang werus.

Penelitian ini bertujuan untuk menganalisa pengaruh asam laktat terhadap kandungan protein dan lemak total serta untuk menentukan kandungan protein dan lemak total yang terdapat dalam udang werus setelah penambahan asam laktat yang bersifat antimikroba dari sauerkraut selama penyimpanan.

Udang merupakan salah satu produk perikanan yang memiliki keistimewaan karena nilai gizinya tinggi dan aromanya spesifik.

Adapun komposisi kimia daging udang adalah sebagai berikut [6]:

Tabel 1 Komposisi Kimia Daging Udang

\begin{tabular}{|l|l|}
\hline $\begin{array}{l}\text { Zat kimia yang } \\
\text { terkandung }\end{array}$ & Prosentase $(\%)$ \\
\hline Air & $71,5-79,6$ \\
Protein & $18-22$ \\
Lemak & 23 \\
Kalsium & 0,0542 \\
Magnesium & 0,421 \\
Fosfor & 0,2285 \\
Besi & 0,002185 \\
Tembaga & 0,003973 \\
Iodium & 0,000023 \\
\hline
\end{tabular}

Sumber : Purwaningsih, 1995.

Proses penurunan mutu udang disebabkan oleh faktor-faktor yang berasal dari badan udang itu sendiri dan faktor lingkungan. Kemunduran mutu udang segar sangat berhubungan dengan komposisi kimia dan susunan tubuhnya. Penurunan mutu ini terjadi secara autolisis, bakteriologis, dan oksidasi [7].

Kubis sebagai suatu komoditi dapat diawetkan dalam keadaan alami untuk waktu yang pendek atau dapat dilakukan dengan fermentasi bakterial, yang dikendalikan dengan garam. Selama fermentasi, asam yang terbentuk bertindak sebagai suatu pengawet selain untuk mengembangkan suatu cita rasa yang dikehendaki. Sauerkraut adalah perkataan Jerman yang menyatakan rajangan kubis bergaram yang difermentasi di Eropa Barat [8].

Bakteri yang aktif dalam proses fermentasi sauerkraut akan memecah senyawa gula yang terdapat dalam sayuran menjadi asam laktat, asam asetat, alkohol, ester, $\mathrm{CO}_{2}$, dam lainlain. Senyawa inilah yang menyebabkan sauerkraut mempunyai bau dan rasa yang khas.

Pada awal fermentasi "sauerkraut", bakteri yang aktif adalah Aerobacter cloaceae yang memproduksi gas dan asam-asam volatil, serta Flavobacterium rheanus. Kedua bakteri tersebut berperan dalam pembentukan flavor sauerkraut. Selanjutnya Leuconostoc mesenteroides meneruskan fermentasi dengan memproduksi asam sampai 0,7 $1,0 \%$ (sebagai asam laktat). Setelah itu tumbuh Lactobacillus plantarum yang meneruskan produksi asam laktat sehingga keasaman mencapai $1,5-2,0 \%$ [9].

Bakteri asam laktat merupakan kelompok spesies bakteri yang mempunyai kemampuan untuk membentuk asam laktat dari metabolisme karbohidrat dan tumbuh pada $\mathrm{pH}$ lingkungan yang rendah. 
Bakteri asam laktat merupakan kelompok bakteri berbentuk batang atau kokus yang mempunyai karakteristik gram positif, tidak membentuk spora, tidak motil, tidak membentuk pigmen, katalase negatif dan asam laktat sebagai senyawa utama hasil fermentasi karbohidrat.

Asam laktat, $\mathrm{CH}_{3} \mathrm{CHOHCOOH}$, adalah salah satu asam-asam organik. Prinsip utama pembuatan asam laktat dengan proses fermentasi ialah pemecahan laktosa menjadi bentuk monosakaridanya dan dari monosakarida ini dengan bantuan enzim laktosa yang dihasilkan oleh bakteri dari jenis Lactobacillus sp. akan diubah menjadi asam laktat [11].

Peneraan jumlah protein dalam bahan makanan umumnya dilakukan berdasarkan peneraan empiris (tidak langsung) [12]. Metode yang tersederhana dan cukup akurat adalah analisa Kjeldahl. Kuantitas dari protein dapat dihitung [13].

Analisa lemak dapat dilakukan dengan menggunakan salah satu contoh ekstraksi padat cair yang berkesinambungan yaitu ekstraksi soklet [14].

\section{METODOLOGI PENELITIAN}

\section{Persiapan Bahan Dan Kultur BAL} Dari Sauerkraut

Bakteri asam laktat (BAL) yang diperoleh diisolasi pada hari ke-4 (Srikandi fardiaz, 1997).

\section{Isolasi Dan Inokulasi BAL Pada Medium NA}

Suspensi contoh hasil pengenceran $10^{-6}$ sebanyak $0,5 \mathrm{~mL}$ dituangkan ke dalam cawan petri yang berisi medium NA secara aseptik. Inkubasi dilakukan pada suhu ruang selama 48 jam.
Seleksi Primer Bakteri Asam Laktat

Seleksi primer dilakukan melalui uji morfologi yaitu pemeriksaan mikroskopik dan pewarnaan gram. BAL ditunjukkan dengan timbulnya warna biru tua atau ungu yang merupakan sifat gram positif.

\section{Seleksi Sekunder Bakteri Asam Laktat \\ BAL dalam medium NA} diinokulasikan ke dalam medium NB dan diinkubasi pada suhu ruang selama 2 hari. Seleksi sekunder BAL meliputi uji katalase. Uji positif ditandai dengan terbentuknya gelembung-gelembung oksigen.

\section{Uji Asam Laktat}

Uji asam laktat meliputi uji kualitatif dan kuantittatif. Uji kualitatif dilakukan dengan menggunakan $\mathrm{FeCl} 3$. Uji positif ditandai dengan timbulnya warna kuning kehijauan pada larutan.

Uji kuantitatif asam laktat dilakuakn dengan metode titrasi asambasa menggunakan larutan standart 0,1 $\mathrm{M} \mathrm{NaOH}$ menggunakan indikator phenolphtalein. Akhir titrasi ditandai dengan berubahnya warna larutan menjadi merah muda.

\section{Evaluasi Organoleptik Udang Setelah Penambahan Asam Laktat dari Sauerkraut}

Udang yang digunakan adalah udang werus segar yang masih hidup dengan umur udang dihitung dari pengambilan sampai ditangani di laboratorium. Udang werus segar dipotong bagian kepalanya, dicuci bersih dengan aquades, ditutup rapat dengan aluminium foil kemudian disimpan di dalam lemari pendingin dengan suhu $5-6^{\circ} \mathrm{C}$. 
Pengawetan dengan penambahan asam laktat sintetik ini untuk mengetahui hanya asam laktat yang berperan dalam pengawetan udang werus. dengan aluminium foil kemudian disimpan dalam lemari es.

Sebagai kontrol yaitu udang werus segar tanpa penambahan sauerkraut.

Evaluasi organoleptik udang yang dilakukan secara visual terhadap kesegaran udang werus secara umum meliputi bau, penampakan dan tekstur.

\section{Analisa Kandungan Protein Dan Lemak Total}

Dalam penelitian ini protein dan lemak total diisolasi dari cuplikan udang werus (aditif dan kontrol).

Analisa kandungan protein menggunakan metode kjeldahl. Satu gram cuplikan ditumbuk halus, bersama-sama dengan 7,5 gram $\mathrm{K}_{2} \mathrm{SO}_{4}$; 0,35 gram $\mathrm{HgO} ; 15 \mathrm{~mL} \mathrm{H}_{2} \mathrm{SO}_{4}$ pekat dimasukkan ke dalam labu kjeldahl 100 $\mathrm{mL}$ dan dipanaskan pada pemanas listrik dalam lemari asam, pemanasan diakhiri setelah cairan menjadi jernih. Labu kjeldahl didinginkan, ditambah dengan $100 \mathrm{~mL}$ aquades dan 0,5 gram logam $\mathrm{Zn}$ setelah itu didinginkan kembali dalam air es. Ditambahkan 0,1 $\mathrm{M} \mathrm{NaOH}$ perlahan-lahan ke dalam larutan sampai larutan bersifat basa, kemudian didestilasi. Destilat ditampung dalam erlenmeyer yang berisi $50 \mathrm{~mL} 0,1 \mathrm{M} \mathrm{HCl}$ dan 5 tetes indikator metil merah. Destlasi diläkukan sampai diperoleh destilat sebanyak $75 \mathrm{~mL}$ atau destilat yang keluar tidak bersifat basa. Kelebihan $0,1 \mathrm{~N} \mathrm{HCl}$ dalam destilat dititrasi dengan larutan basa standart $0,1 \mathrm{M}$ $\mathrm{NaOH}$.

\section{Analisa kandungan lemak total menggunakan metode ekstraksi soklet.}

Cuplikan udang werus (aditif dan kontrol) masing-masing seberat 60 gram ditumbuk halus, dikeringkan di dalam oven dan ditimbang berat keringnya sampai didapatkan berat konstan. Homogent yang diperoleh diekstraksi dengan alat "extractor soklet" menggunakan campuran larutan pengekstraksi metanol:kloroform 1:1 $(\mathrm{v} / \mathrm{v})$. Ekstraksi dilakukan pada suhu $70^{\circ} \mathrm{C}$ selama 4 jam atau sampai pelarut tidak menunjukkan warna kuning. Pelarut yang terdapat pada hasil ekstraksi diuapkan dengan evaporator. Lemak yang diperoleh ditimbang.

\section{HASIL DAN PEMBAHASAN}

\section{Persiapan Bahan dan Kultur BAL}

Sauerkraut adalah hasil fermentasi bakterial dari kubis yang dikendalikan dengan garam. Selama fermentasi, terbentuk asam yang dapat berfungsi sebagai bahan pengawet.

\section{Seleksi Primer BAL}

Hasil pengujian menunjukkan bahwa bakteri berbentuk batang dan berwarna biru tua sehingga dapat dikatakan bersifat gram positif. Kedua sifat ini sesuai dengan karakteristik dari BAL

\section{Seleksi Sekunder BAL}

Hasil pengujian menunjukkan tidak terbentuknya gelembung-gelembung oksigen pada biakan bakteri sehingga dapat dikatakan bersifat katalase negatif. Hal ini berarti biakan bakteri yang ada dalam sauerkraut tersebut adalah BAL. 


\section{Uji Asam Laktat}

Uji kualitatif asam laktat dengan $\mathrm{FeCl} 3$ menunjukkan uji positif yaitu timbulnya warna kuning kehijauan pada larutan. Dari hasil ini menandakan bahwa sauerkraut mengandung asam laktat.

Uji kuantitatif asam laktat dengan larutan $0,1 \mathrm{M} \mathrm{NaOH}$ menunjukkan kandungan asam laktat dalam sauerkraut sebesar $0,02 \mathrm{M}$. Kandungan asam laktat ini diperoleh setelah 4 hari waktu fermentasi sauerkraut.

Tabel 2. Hasil uji kuantitatif asam laktat

\begin{tabular}{|c|c|c|}
\hline Titrasi & $\begin{array}{c}\text { Volume } \\
\text { asam laktat } \\
(\mathrm{mL})\end{array}$ & $\begin{array}{c}\text { Volume } \\
0,1 \mathrm{MNaOH} \\
(\mathrm{mL})\end{array}$ \\
\hline 1 & 10 & 2,1 \\
2 & 10 & 2,0 \\
3 & 10 & 1,9 \\
\hline
\end{tabular}

\section{Evaluasi Organoleptik Udang} Setelah Penambahan Asam Laktat dari Sauerkraut

Cuplikan yang digunakan adalah udang werus segar (Metapenaeus monoceros) tanpa bagian kepala dengan umur udang $1 / 2$ jam. Bagian kepala udang sangat berpengaruh terhadap daya simpan karena bagian ini merupakan sumber bakteri pembusuk. Oleh karena itu, bagian ini segera dibuang sebelum proses pengawetan dimulai.

Pengawetan dilakukan pada suhu dingin disebabkan udang mengalami proses pembusukan sangat cepat ibandingkan dengan produk perikanan lainnya. Dalam waktu kurang lebih 1 jam setelah penangkapan dan setelah melewati masa kekakuan maka udang akan segera membusuk dan dipakai waktu penyimpanan $0,2,4,6$ dan 8 jam karena setelah 8 jam waktu penyimpanan udang werus telah busuk.

Evaluasi organoleptik udang werus meliputi bau, penampakan dan tekstur daging udang werus selama penyimpanan dengan batas waktu tersebut, bau dari udang werus masih dalam batas yang masih dapat diterima, daging udang werus tampak putih dan teksturnya masih kenyal. Hal di atas menunjukkan bahwa udang werus masih dalam keadaan segar.

\section{Pengaruh Penggunaan Asam Laktat Terhadap Kandungan Protein Udang Werus Selama Penyimpanan \\ Pengaruh penggunaan asam laktat sebagai bahan pengawet udang werus terhadap kandungan protein dapat dilihat pada gambar 1.}

Tabel 3 Kandungan protein udang werus dengan variasi waktu penyimpanan. (A) Dengan penambahan asam laktat dari sauerkraut $0,02 \mathrm{M}$; (B) Dengan penambahan asam laktat sintetik $0,02 \mathrm{M}$; (C) Tanpa penambahan asam laktat/kontrol

\begin{tabular}{|c|c|c|c|}
\hline $\begin{array}{c}\text { Waktu } \\
\text { penyimpanan (Jam) }\end{array}$ & $\begin{array}{c}\text { Protein (\%) } \\
\text { (A) }\end{array}$ & $\begin{array}{c}\text { Protein (\%) } \\
\text { (B) }\end{array}$ & $\begin{array}{c}\text { Protein (\%) } \\
(\mathrm{C})\end{array}$ \\
\hline 0 & 29,85 & 29,85 & 29,85 \\
2 & 27,05 & 26,79 & 24,75 \\
4 & 22,50 & - & - \\
6 & 20,22 & - & - \\
8 & 16,28 & 17,51 & 12,17 \\
\hline
\end{tabular}




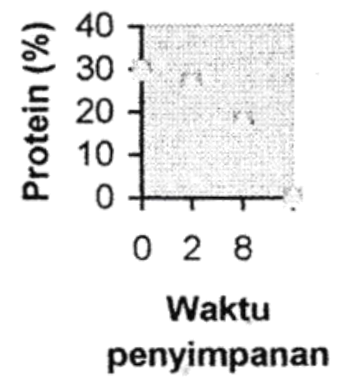

A

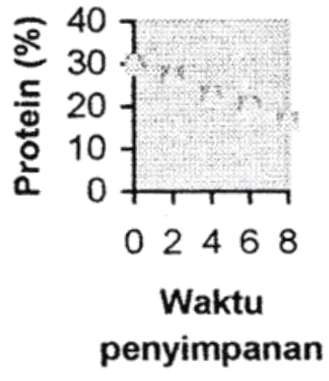

B

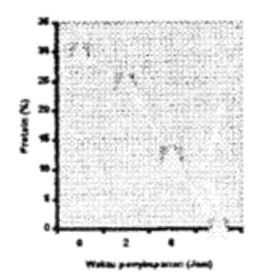

C

Gambar 1 Pengaruh waktu penyimpanan terhadap kandungan protein udang werus. (A) Dengan penambahan asam laktat dari sauerkraut $0,02 \mathrm{M}$; (B) Dengan penambahan asam laktat sintetik $0,02 \mathrm{M}$; (C) Tanpa penambahan asam laktat/kontrol

Dari gambar 1 di atas tampak bahwa dengan penambahan asam laktat yang terkandung dalam sauerkraut kandungan protein mengalami penurunan yang lebih kecil ibandingkan dengan kontrol. Ini terlihat pada 8 jam penyimpanan, dengan penambahan asam laktat kandungan protein udang werus mengalami penurunan dari $29,85 \%$ menjadi $16,28 \%$ sedangkan untuk kontrol dari $29,85 \%$ menjadi $12,17 \%$. Hal ini disebabkan asam laktat sebagai bahan pengawet dapat menghambat pertumbuhan bakteri- bakteri pembusuk pada daging udang werus, sehingga protein yang iuraikan oleh bakteri-bakteri tersebut lebih sedikit dibandingkan dengan tanpa penambahan asam laktat.

Pengaruh Pengguinaan Asam Laktat Terhadap Kandungan Lemak Total Udang Werus Selama Penyimpanan

Pengaruh Penggunaan asam laktat sebaai bahan pengawet terhadap kandungan lemak total dapat dilihat pada gambar 2 .

Tabel 4 Kandungan lemak total udang werus dengan variasi waktu penyimpanan. (A) Dengan penambahan asam laktat dari sauerkraut $0,02 \mathrm{M}$; (B) Dengan penambahan asam laktat sintetik $0,02 \mathrm{M}$; (C) Tanpa penambahan asam laktat/kontrol.

\begin{tabular}{|c|c|c|c|}
\hline $\begin{array}{c}\text { Waktu penyimpanan } \\
\text { (Jam) }\end{array}$ & $\begin{array}{c}\text { Lemak total (\%) } \\
(\mathrm{A})\end{array}$ & $\begin{array}{c}\text { Lemak total (\%) } \\
(\mathrm{B})\end{array}$ & $\begin{array}{c}\text { Lemak total (\%) } \\
(\mathrm{C})\end{array}$ \\
\hline 0 & 8,33 & 8,33 & 8,33 \\
2 & 7,73 & 8,17 & 1,63 \\
4 & 6,67 & - & - \\
6 & 1,42 & - & - \\
8 & 1,33 & 2,17 & 1,32 \\
\hline
\end{tabular}




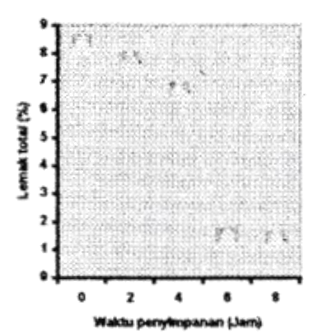

A

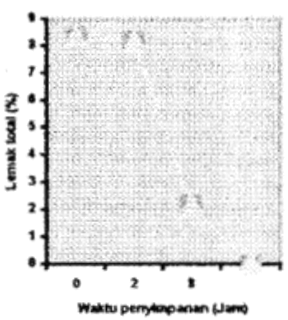

B

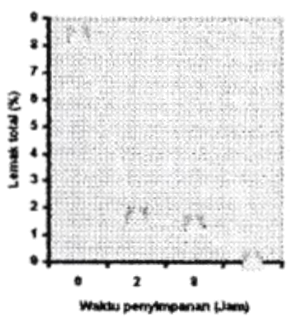

- $\mathbf{C}$

Gambar 2 Pengaruh waktu penyimpanan terhadap kandungan lemak total udang werus. (A) Dengan penambahan asam laktat dari sauerkraut 0,02M; (B) Dengan penambahan asam laktat sintetik $0,02 \mathrm{M}$; (C) Tanpa penambahan asam laktat/kontrol.

Dari gambar 2 di atas tampak bahwa kandungan lemak total mengalami penurunan dengan bertambahnya waktu penyimpanan.

Penurunan kandungan lemak total pada daging udang werus dengan penambahan asam laktat dan tanpa penambahan relatif sama yaitu sebesar $84,03 \%$ dan $84,15 \%$. Artinya baik dengan penambahan asam laktat maupun kontrol kandungan lemak total tetap turun. Adanya asam laktat yang itambahkan sebagai bahan pengawet akan menghambat aktivitas tumbuh bakteri-bakteri pembusuk pada daging udang werus tetapi selain itu asam laktat juga akan menghidrolisa lemak total sehingga kandungan lemak total menjadi turun.

Maka dari uraian di atas dapat dikatakan bahwa penambahan asam laktat dari sauerkraut berpenaruh terhadap kandungan lemak total udang werus.

\section{KESIMPULAN}

Dari hasil penelitian dapat diambil kesimpulan bahwa penambahan asam laktat dari sauerkraut sebagai bahan pengawet berpengaruh terhadap kandungan protein dan lemak total udang werus (Metapenaeus monoceros). Setelah 8 jam penyimpanan, dengan penambahan asam laktat dari sauerkraut sebesar 0,02 $M$ dapat mempertahankan kandungan protein yaitu dari $29,85 \%$ menjadi $16,28 \%$ bila dibandingkan dengan kontrol yaitu dari $29,85 \%$ menjadi $12,17 \%$. Sedangkan terhadap lemak total, penambahan asam laktat tersebut berpengaruh karena dapat menurunkan kandungan lemak total yang relatif sama yaitu $84,03 \%$ bila ditambahkan asam laktat dari sauerkraut dan $84,15 \%$ bila tanpa penambahan asam laktat.

\section{DAFTAR PUSTAKA}

1. Astawan, Made, Mengenal Makanan Tradisional (2) Produk Olahan Ikan, Buletin Teknologi dan Industri Pangan, Vol VIII, No. 3, 1997, Hal 58.

2. Ilyas, Sofyan, Teknologi Refrigerasi Hasil Perikanan, Jilid I, Jakarta, 1983, Hal 18. 
3. Lidgren, S.E., W.J. Dobrogosz, Antagonistic Activities of Lactic acid Bacteria in Food and Feed Fermentation,

FEMS

Microbiology Review. 87, 1990, Hal 149-164.

4. Fardiaz, Srikandi, Sri Laksmi Jenie, Ati Solihati, Isolasi dan Seleksi Bakteri Asam Laktat Yang Bersifat Antimikroba dari Sauerkraut, Buletin Teknologi dan Industri Pangan, Vol VIII, No. 3, 1997, Hal 13.

5. Jenie, B. Sri Laksmi, Harsi D. Kusumaningrum, Maman Firmansyah, Kombinasi Kultur Campuran Bakteri Asam Laktat, Natrium Klorida dan Natrium Asetat Untuk Pengawetan Ikan Lemuru, Buletin Teknologi dan Industri Pangan, Vol VIII, No. 3, 1997, Hal 32.

6. Purwaningsih, Sri, Teknologi Pembekuan Udang, Penebar Swadaya, Jakarta, 1995, Hal 1-2.

7. Ibid 6, Hal 5-7.

8. Desrosier, Norman W., Teknologi Pengawetan Pangan, edisi ketiga,
UI-Press, Jakarta, 1988, Hal 344346.

9. Judoamidjojo, R. Muljono,dkk, Biokonversi, PAU-Bioteknologi IPB, Bogor, 1989, Hal 209.

10. Sudarmaji, S., Mikrobiologi Pangan, PAU-Pangan dan Gizi UGM, Yogyakarta, 1989, Hal 135136.

11. Said,E., Gumbira, Bioindustri : Penerapan Teknologi Fermentasi, edisi kesatu, PT Meditama Sarana Perkasa, Jakarta, 1987, Hal 256257.

12. Sudarmaji, Slamet, Bambang Haryono, Suhardi, Analisa Bahan Makanan dan Pertanian, PAUPangan dan Gizi UGM, Yogyakarta, 1996, Hal 120-121.

13. Christian, Gary D., Analytical Chemistry, edisi keempat, John Wiley \& Sons, Singapore, 1986, Hal 116-117.

14. Vogel's, Textbook of Practical Organic Chemistry, edisi keempat, Longman London and New York, 1984, Hal 137. 